that the income of the professors and teachers shall be independent of the number of students whom they can attract. In this way you provide against the danger, patent elsewhere, of finding attempts at improvement obstructed by vested interests; and in the department of medical education especially, you are free of the temptation to set loose upon the world men utterly incompetent to perform the serious and responsible duties of their profession.

It is a delicate matter for a stranger to the practical working of your institutions, like myself, to pretend to give an opinion as to the organisation of your governing power. I can conceive nothing better than that it should remain as it is, if you can secure a succession of wise, liberal, honest, and conscientious men to fill the vacancies that occur among you. I do not greatly believe in the efficacy of any kind of machinery for securing such a result, but I would venture to suggest that the exclusive adoption of the method of co-optation for filling the vacancies which must occur in your body appears to me to be somewhat like a tempting of Providence. Doubtless there are grave practical objections to the appointment of persons outside of your body and not directly interested in the welfare of the university; but might it not be well if there were an understanding that your academic staff should be officially represented on the board, perhaps even the heads of one or two independent learned bodies, so that academic opinion and the views of the outside world might have a certain influence in that most important matter, the appointment of your professors? I throw out these suggestions, as I have said, in ignorance of the practical difficulties that may be in the way of carrying them into effect, on the general ground that personal and local influences are very subtle, and often unconscious, while the future greatness and efficiency of the noble institution which now commences its work must largely depend upon its freedom from them.

I constantly hear Americans speak of the charm which our old mother country has for them, of the delight with which they wander through the streets of ancient towns, or climb the battlements of mediæval strongholds, the names of which are indissolubly associated with the great epochs of that noble literature which is our common inheritance; or with the blood-stained steps of that secular progress, by which the descendants of the savage Britons and of the wild pirates of the North Sea have become converted into warriors of order and champions of peaceful freedom, exhausting what still remains of the old Berserk spirit in subduing nature, and turning the wilderness into a garden. But anticipation has no less charm than retrospect, and to an Englishmen landing upon your shores for the first time, travelling for hundreds of miles through strings of great and well-ordered cities, seeing your enormous actual, and almost infinite potential, wealth in all commodities, and in the energy and ability which turn wealth to account, there is something sublime in the vista of the future. Do not suppose that 1 am pandering to what is commonly understood by national pride. I cannot say that I am in the slightest degree impressed by your bigness, or your material resources, as such. Size is not grandeur, and territory does not make a nation. The great issue, about which hangs a true sublimity, and the terror of overhanging fate, is what are you going to do with all these things? What is to be the end to which these are to be the means?. You are making a novel experiment in politics on the greatest scale which the world has yet seen. Forty millions at your first centenary, it is reasonably to be expected that, at the second, these states will be occupied by two hundred millions of English-speaking people, spread over an area as large as that of Europe, and with climates and interests as diverse as those of Spain and Scandinavia, England and Russia. You and your descendants have to ascertain whether this great mass will hold together under the forms of a re- public, and the despotic reality of universal suffrage; whether state rights will hold out against centralisation without separation; whether centralisation will get the better without actual or disguised monarchy; whether shifting corruption is better than a permanent bureaucracy; and as population thickens in your great cities, and the pressure of want is felt, the gaunt spectre of pauperism will stalk among you, and communism and socialism will claim to be heard. Truly America has a great future before her; great in toil, in care, and in responsibility; great in true glory if she be guided in wisdom and righteousness; great in shame if she fail. I cannot understand why other nations should envy you, or be blind to the fact that it is for the highest interest of mankind that you should succeed; but the one condition of success, your sole safeguard, is the moral worth and intellectual clearness of the individual citizen. Education cannot give these, but it can cherish them and bring them to the front in whatever station of society they are to be found; and the universities ought to be and may be the fortresses of the higher life of the nation.

May the university which commences its practical activity to-morrow abundantly fulfil its high purpose ; may its renown as a seat of true learning, a centre of free inquiry, a focus of intellectual light, increase year by year, until men wander hither from all parts of the earth, as of old they sought Bologna, or Paris, or Oxford.

And it is pleasant to me to fancy that among the English students who are drawn to you at that time there may linger a dim tradition that a countryman of theirs was permitted to address you as he has done today, and to feel as if your hopes were his hopes and your success his joy.

\section{REV. HIARK PATTISON ON UNIVERSITY REFORM}

$\mathrm{NE}$ of the most valuable addresses at the Social Science Congress at Liverpool was that by the Rev, Mark Pattison, last Friday, on the subject of Education. He confined his remarks mainly to Lord Sandon's Bill and the Oxford and Cambridge Bills. In passing, however, he spoke in the strongest terms of the miserable state of the middle-class schools, "the wretched destitution of all intellectual nourishment in which the middle classes of England grow up." With regard to the Education Bill, Mr. Pattison showed that elementary education was in anything but a satisfactory condition, that as yet we have only the beginning of a school system. He then spoke at considerable length on the Oxford and Cambridge Bills, which our readers will remember were withdrawn last session on the distinct understanding that they should be introduced next session. Mr. Pattison referred to the scheme for endowing the University at the expense of the Colleges, and to Lord Salisbury's declaration that one purpose of the measure was "to promote science and learning." Mr. Pattison went on to say :--" When the Oxford Bill got down into the Commons the member of the Cabinet who had the charge of it there hastened to disavow any such intentions on the part of his Government. Lord Salisbury's declaration had been made in the House of Lords, and in the Upper House it did not seem altogether absurd to speak of science and learning in connection with a University. But such flimsy and unpractical notions are not for the atmosphere of the Lower House. Members of the Government in the Lower House vied with each other in eagerly repudiating any intention of making the University a seat of learning and science. This had been an unauthorised escapade of their impulsive colleague in the Lords. This disavowal was well received in the House. Antagonism was half disarmed. The member of the learned University of Oxford received the congratulations of the member of the learned University of Lon. 
don in having done with all that nonsense. The Bill that has been dropped was a Bill empowering certain commissioners to take funds now devoted to College purposes and devote them to university purposes. What these university purposes are is not stated-is not known-not known even to the promoters of the Bill. All that is known is that among those purposes is not the promotion of science and learnings. This purpose, which was announced by Lord Sali-bury, has been anxiously disavowed by Lord Salisbury's colleagues. In these circumstances it cannot be any great matter for regret that the Universities Bill should have been laid aside."

Mr. Pattison then spoke of the University itself. $\mathrm{He}$ briefly showed how our two great universities, from being national, became State Church institutions, and that notwithstanding the abolition of the Test Act, the ecclesiastical spirit is still practically supreme.

Something might be done to counteract this sinister influence by opening the headships of colleges to laymen, and by attaching to the University a number of eminent men of science. The universities, moreover, he went on to show, are anjthing but popular; with a population of twenty-one millions, and realised property of 6,000 millions, the total number of university students does not exceed 6,000 out of I I 4,000 males between eighteen and twenty-one that ought to be receiving a high-class education. This state of things, Mr. Pattison justly says, can be described as nothing less than a state of national clesticution-an intellectual blight. It is not the mere cost, though this is large enough as contrasted with the cost of university education in Scotland and Germany, that deters the middle classes from sending their sons to a university, it is the prevalent belief that, unless to a professional man, a university education is worse than useless. Mr. Pattison then went on to show what he thinks a university ought to be.

"Universities are not to fit men for some special mode of gaining a livelihood; their object is not to teach law or divinity, banking, or engineering, but to cultivate the mind and form the intelligence. A university should be in possession of all science and all knowledge, but it is as science and knowledge, not as a money-bringing pursuit, that it possesses it. There is an old saying-so old that it is quite forgotten even in the universities-' $A$ university is founded on arts' - founded, that is, its fabric of the special sciences is raised upon the liberal studies. Men are men, whether they are lawyers or physicians, merchants or manufacturers-they possess an intellect and a conscience; and it is with these as men, and not as lawyers or physicians, merchants or manufacturers, that liberal education has to do. What professional men should carry away with them from the university is not professional knowledge, but that which directs the use of their professional knowledge, and brings the light of general culture to illuminate the technicalities of a special pursuit. To go to Cambridge, like the youth in the old Latin grammar, "ad capiendum ingenii cultum," seems to the practical Englishman like telling him to feed on moonshine. The idea of education is a lost idea among the middle classes. When his school-time is over-and a very unprofitable time it has mostly been to him-he can't conceive that there is anything beyond, except qualifying for a bread-winning profession. The reason why the son of a wealthy middle-class family is not at the university is exactly the same as the reason why the son of a day-labourer is not at the village school. $\mathrm{He}$ does not see the good of it."

Mr. Pattison then referred to a statement made by Mr. Smith, of Halifax, at the Brighton meeting, that if parents saw their way to getting 5 per cent. on the sum laid out on a girl's education, then they would be as ready to spend $2,000 l$. on that as they are on a boy's.

"Mr. Smith, of Halifax, was very likely worth thousands; but his view is precisely the view of John Nokes, the day-labourer in our village, who doesn't want his boy 'to have no school-larning; he never saw no good come of it ; the boy don't get more wages by it.' John Nokes earns twenty shillings a week ; Mr. Smith, of Halifax, has 5 per cent. upon many thousands of pounds; but their ideas of education are the same-no sense of the value of life, of the intrinsic worth of the human soul, and of its capacities for being trained. Man or woman is a machine for earning an income. The charm and beauty of life, as it can be lived and adorned, is wholly unknown. The work of the British workman, we say, is deteriorated because he cares nothing for the work itself, but only for the wages it is to bring him in. At this we are all indig nant. We have little right to be so, when we ourselves care as little for life for life's sake as he does for art for art's sake. It may be confidently asserted, then, that the universities in any country cannot rise above public instruction generally. They may fall below it."

Mr. Pattison then showed that the great reforms in the Oxford University curriculum during the last sixty or seventy years have been forced upon her from without.

"It is no longer now a question of breaking up the old monopoly of Latin and Greek, and of the introduction of a few popular branches of instruction by the side of the old. A far wider conception of a university has now been opened up, and of the function it is expected to fulfil for the nation at large. This conception is a consequence of the position which science has come to occupy in the world in the last quarter of a century. When scientific men had to speak to the wider public fifty years ago they used to dwell on the various applications of science to the arts of life. The industrial value of scientific knowledge had then to be inculcated. It was from this point of view that science first got recognition. This has been successfully done. Facts stronger than arguments have sufficiently proved the utility of scientific knowledge. On this point no more needs to be said. The public are alive to the truth. But a new consideration now emerges out of this proved utility. Science has been incessantly growing since the close of the great European war of 1815 . It has been extending its boundaries, enlarging its mass, increasing its complexity, disclosing inner harmonies, and bringing the world of thought, of work, of life within its grasp. All this growth and movement has taken place outside the universities. Our most considerable names in science have often not been university men; when they have been so their scientific activity has been quite apart from their university employment. This scientific atmosphere, this consciousness of a common aim and a common inspiration among a multitude of labourersthis active pursuit of truth, which forms a bond as strong as the bond of charity-this is not the atmosphere of our universities. There exists, then, in the world outside a vast body of knowledge, of the importance of which intelligent people are well aware. And there exist inside the universities, colleges with considerable endowments. What is more natural than the wish to bring these two separate existences together? How are we to provide for the maintenance and transmission of all this rich treasure of knowledge which has been painfully accumulating in the past? Can a more proper place for the purpose be found than in our, universities? A university, says Prof. Huxley, is a corporation which has charge of the interests of knowledge as such, the business of which is to represent knowledge by the acquirements of its members and to increase it by their studies. The change demanded consists in a change of the atmosphere of the university, in the diffusion of a disinterested love of innowledge. It may be that legislation can do little to promote it. But there is one change which legislation only can make, and which is a necessary condition of the establishment of a system of scientific study and instruction. This is the removal of the fellowship system. The history of this peculiar institution has been often given of late, and the 
time does not now allow of my repeating it. Suffice it to say that the present operation of these valuable prizes is directly antagonistic to their supposed objects. Instead of promoting science and learning they serve only to make the university an arena in which young men contend for money prizes, and those who should be teachers are engrossed in training, handicapping, and settling the conditions of the race. The operation of emulation, honours, and prizes as a stimulus in school education is somewhat doubtful. But in the highest stage of liberal eacucation it is necessary, if science and letters are to work with their cultivating effect on the mind, that they should be disengaged from all mercenary attractions. But when prizes of such magnitude as Fellowships are employed to attract students they become themselves the all-engrossing objects of pursuit. In Oxford and Cambridge, taken togetber, an amount of not less than $150,000 l$. a-year is spent on prizes. The sum is in itself an insignificant fraction of the national income, but it far exceeds the whole outlay which the country makes on science and learning. The bestowal of these lavish prizes corrupts instruction at its sources. No reform, having for its object to make the universities the home of science and learning, can be effectual which does rot begin by suppressing this wholesale pensioning of youthful sinecurists. I have reminded you of one old academical saying; there is another which recurs now to my recollection, 'A Fellowship is the grave of learning.' I have spoken only of our old Universities, or rather of Oxford, because I know it best. But I must not forget that there are younger institutions which are struggling upwards towards the ideal of a university, as I have described it in Prof. Huxley's words, 'a corporation which has charge of the interests of knowledge as such.' At the head of these I must place Owens College, not only because it is in Lancashire, but because in its staff of Professors it possesses a body of men who are truly representative of knowledge in a variety of its most important departments. In a single generation we have seen this College rise from humble beginnings to a position in which it can put forward a claim to be incorporated as a university, with the privilege of giving degrees. Its capitalised sources are, indeed, small. In addition to the original 100,000 l. of Owens' bequest, about $220,000 l$. has been contributed by voluntary subscribers, an insignificant sum when compared with the wealth of the great manufacturing metropolis. These funds, too, have been raised almost exclusively in a very small circle and by a very few public-spirited individuals ; they have not been drawn frorn the general mass of manufacturing wealth in Manchester or the neighbouring district. With material means so inadequate, the scientific eminence attained by this young institution is a remarkable example of intellectual vigour, which must dispose us to regard favourably its claims to incorporation. But there is, besides, an immediate practical requirement which compels $O$ wens College to seek without delay theright of conferring degrees. It is this: that as long as its students are under the necessity of graduating through the University of London, they must pass through the examinations required for the London degree. Consequently the professors of Owens College can never take the free and independent position of teachers of science. It is inevitable that they must prepare their pupils for examination, and every true teacher knows too well that this process is incompatible with genuine instruction in letters and science. The efficiency of a local university is not to be measured by the amount of its annual income, nor its success by the number of its pupils. Does it profess to teach and represent human knowledge in all its main branches and in its most complete forms? Is each great department occupied by men who are in possession of the long tradition of the past and zealous in searching out what still remains unexplored? Is liberal culture recognised as it; basis, and progressive science as its aim? Where these conditions are fulfilled it would be hard to say why such an institu. tion should not be entrusted by the State with the privilege of marking its students with the public stamp of certified acquirement. If it were merely a question of comparative qualification it would be difficult to maintain that Durham possesses, and that Owens College does not possess, the capacities, extensive and intensive which I have supposed to be required. But if in the next twenty years the growth of Owens College is in proportion to its advance in the last twenty, the question will by that time have settled itself."

No words of ours could add to the force of this address, coming as it does from one in the position of its author. When we contrast the actual state of things in our English Universities with the ideal which appears in the above address and in that of Prof. Huxley at Baltimore-an ideal which has almost become a reality in America-any wellwisher of his country and of learning cannot but feel regret at the opportunities that have been lost, and the almost hopelessness of any rapid improvement.

\section{THE FIFTH MEETING OF IUUSSIAN NATURALISTS}

THE fifth meeting of Russian Naturalists was opened September I2 at Warsaw. The Russian Naturalists are not yet organised into a permanent association, although it is their wish, repeatedly expressed, to found an association on the same principles as the British. A special imperial permission must still be obtained before each meeting, the rules of the meeting being settled by imperial decree, and a sum of money allowed for expenses and publications. The sittings of the sections are open only to members and persons introduced by them, mem bership being allowed only to those who have made direct contributions to science, as ordained by the rules. The meetings of the united sections for the transaction of general business and for lectures of general interest, are held in public, usually in presence of a numerous audience. The meeting (for it can hardly be called an association) publishes a daily bulletin of transactions, and issues, in the course of the year, one or two large volumes of memoirs (Troody) containing lectures, anid longer papers in extenso, together with such contributions as separate societies of naturalists have found too expensive to publish in their journals.

The Warsaw meeting was largely attended by naturalists from all parts of Russia, but especially from St. Petersburg, Moscow having but few representatives. The number of members was about three hundred, the sections of Scientific Medicine and Chemistry being especially full. There were very few foreign naturalists, the organising committee not being allowed by the rules to send invitations abroad. Prof. Brodofsky, president of the Committee, was elected president of the meeting, and the St. Petersburg professors, Mendelefeff and Butleroff, vice-presidents. The ten sections of the meeting transacted a great deal of business during the nine days the Naturalists were assembled, and we may give afterwards some account of the papers read, referring now only to lectures delivered at public meetings.

At the first meeting Prof, Dobrzycki read an interesting medical paper, "On the Principles of Research into the Causes of Diseases." Several propositions as to the permanent organisation of future meetings, the opening of a Society of Naturalists at the Warsaw University on the principles adopted for the societies already existing in connection with all universities in Russia, the holding of an international meeting of naturalists, and the publication of an international daily scientific paper, were read and referred for discussion to the sections.

The second public meeting was especialiy crowded with the public. Two papers were read by Prof. Goyer 